\title{
Mechanical Obstruction of the Small Bowel by a Dried Persimmon, Misdiagnosed as Intussusception
}

\author{
Young Sun Yoo, M.D., Ph.D., Seong Pyo Mun, M.D., Ph.D.
}

Department of Surgery, School of Medicine, Chosun University, Gwangju, Korea
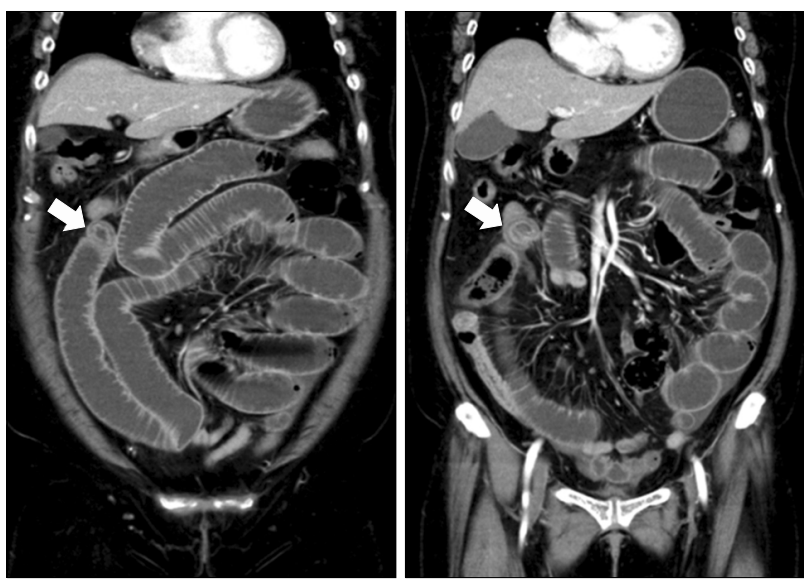

Fig. 1. Abdominal computed tomography showed dilated small bowel and lesion looking like intussusception (arrows).

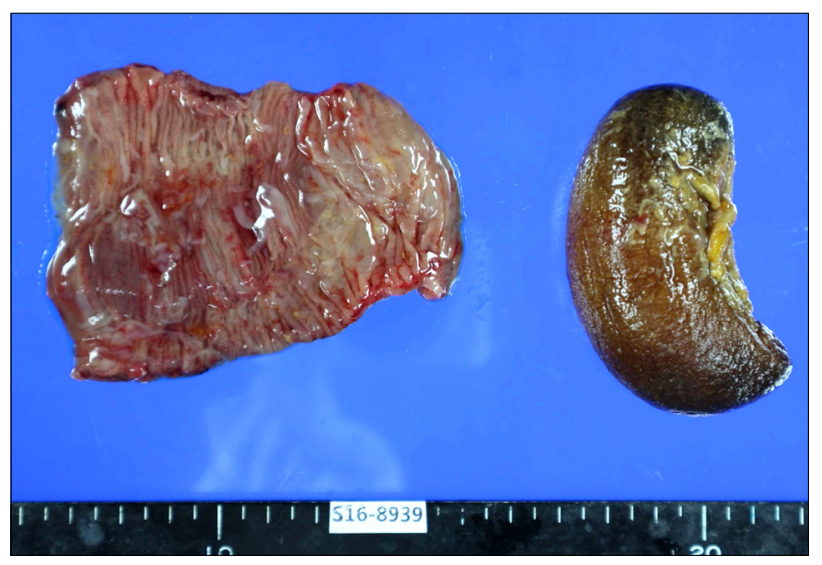

Fig. 2. Foreign body proved to be a dried persimmon. Resected small bowel showed ischemic necrosis of mucosa and muscle and congestion and hemorrhage of submucosa pathologically.

A 67-year-old woman was admitted to the emergency department because of abdominal distention and abdominal pain. The patient first presented to a local hospital because of abdominal pain that started two days prior and was transferred to the emergency department with suspected intussusception. Besides receiving hypertension medication, the patient had no remarkable history of past diseases or abdominal surgeries. Her blood test results were as follows: hemoglobin, $13.8 \mathrm{~g} / \mathrm{dl}$; white blood cell count, 7,720/ $\mathrm{mm}^{3}$; platelet count, 188,000/ $\mathrm{mm}^{3}$; sodium level, $138 \mathrm{mEq} / \mathrm{L}$; potassium level, $3.0 \mathrm{mEq} / \mathrm{L}$; and lactic acid level, $8.0 \mathrm{mg} / \mathrm{dl}$. Abdominal computed tomography revealed distension of the

Received November 1, 2016, Accepted February 1, 2017

Correspondence to: Seong Pyo Mun, M.D., Ph.D.

Department of Surgery, Chosun University Hospital, Euiseongkwan 4204, 365 Pilmundaero, Dong-gu, Gwangju 61453, Korea Tel: +82-62-220-3062, Fax: +82-60-224-3441, E-mail: spmun@chosun.ac.kr ORCID: http://orcid.org/0000-0002-7067-4751 proximal small intestine and intussusception (Fig. 1). Emergency laparotomy was performed, and a $4 \times 8 \mathrm{~cm}$ mass was discovered in the small intestine $200 \mathrm{~cm}$ proximal from the ileocecal valve. The small intestine proximal from the mass was distended, while the distal small intestine beyond the mass was unremarkable. Obstruction of the small bowel by tumor or intussusception was suspected, and a segmental resection of the small intestine was performed. Inspection of the resected portion of the small intestine

Copyright (C) 2018 by Korean Society of Acute Care Surgery

(c) This is an Open Access article distributed under the terms of the Creative Commons Attribution Non-Commercial License (http://creativecommons.org/licenses/by-nc/4.0) which permits unrestricted non-commercial use, distribution, and reproduction in any medium, provided the original work is properly cited. 
revealed a foreign body suspected to be dried persimmon. Reevaluation of the patient's history revealed that the patient had previously swallowed dried persimmon without proper mastication due to tooth problems (Fig. 2). Dried food such as dried persimmon can cause obstruction by absorbing moisture in the small intestine and distending if swallowed whole. As abdominal pain caused by dried food swallowing can be misdiagnosed as small intestinal tumor or intussusception, caution is required [1-3].

\section{Acknowledgments}

This study is supported by research fund of Chosun University Hospital 2016.

\section{Conflicts of Interest}

No potential conflict of interest relevant to this article was reported.

\section{References}

1. Piotto L, Gent R. Dried apricots: an unusual cause of bowel obstruction. Pediatr Radiol 2005;35:1224-6.

2. Gümüs M, Kapan M, Onder A, Tekbas G, Yagmur Y. An unusual cause of small bowel obstruction: dried apricots. J Pak Med Assoc 2011;61:1130-1.

3. Ooi S, Hong K. Small bowel obstruction caused by dried apple. Int J Surg Case Rep 2015;10:154-7. 